\title{
El juramento de la ciudad de México a Luis I de Borbón. El testimonio histórico del gremio de plateros, 1724*
}

\author{
Gonzalo Tlacxani Segura**
}

Recibido el 16 de abril de 2019; aceptado el 13 de agosto de 2019

\section{RESUMEN}

El presente texto analiza un episodio poco conocido de la lealtad indiana hacia la Corona española, que fue el juramento y celebración que hizo la ciudad de México a Luis I de Borbón como "rey y señor de las Españas" en 1724. Caso prácticamente desconocido en la historiografía novohispana y que por primera vez se presenta a partir del testimonio histórico del poder político-económico que dejó el gremio de plateros de México, el cual consideraríamos el principal hallazgo de esta investigación. El mencionado manuscrito no podría ser entendido en este trabajo si no tomáramos a la fiesta pública como fórmula de sociabilidad, y al elemento de la lealtad y obediencia como parte del pacto político-social entre las corporaciones hispánicas con el nuevo monarca..

Palabras clave: fiesta y sociedad, Nueva España, Luis de Borbón, gremio de plateros, siglo XVIII.

* Este trabajo fue presentado originalmente durante las V Jornadas de Jóvenes Americanistas Los laberintos del poder: personas, estrategias, imágenes y textos, celebrado en la Universidad de Sevilla los días 25, 26 y 27 de abril de 2018. Quiero externar mi agradecimiento al doctor Andrés Lira González (El Colegio de México), al maestro Alejandro Wang Romero (Universidad de Sevilla) y a los dos dictaminadores anónimos por sus observaciones y comentarios a este trabajo.

** Centro de Estudios Históricos, El Colegio de México, Ciudad de México, México. Correo electrónico: tlacxanisg@gmail.com. ORCID: https://orcid.org/0000-0003-3062-743X. 


\title{
The oath of the city of Mexico to Luis I of Bourbon. The historical testimony of the silversmith's guild, 1724
}

\begin{abstract}
The present text analyzes a little-known episode of Indian loyalty to the spanish crown, which was the oath and celebration that the city of Mexico made to Luis I de Bourbon as “king and lord of the Spain's” in 1724. Case practically unknown in the novohispana historiography and that for the first time is presented from the historical testimony of the political economic power that left the guild of silversmiths of Mexico, which we would consider the main finding of this investigation. Handwritten text that could not be understood in this work if we did not take the public party, as a formula of sociability, and the element of loyalty and obedience, as part of the social political pact between the Hispanic corporations with the new monarch.
\end{abstract}

Key words: Party and society, New Spain, Luis de Bourbon, silversmiths guild, 18th century.

\section{INTRODUCCIÓN}

— $\mathrm{l}$ tema de la formación política de la Nueva España no podría ser com- 1 prendida adecuadamente si no se tomasen en cuenta las celebraciones civiles y eclesiásticas que formaron parte de la vida cotidiana de los habitantes del virreinato americano. La fiesta representada por medio de procesiones, portadas, pinturas y esculturas fue el mecanismo mediante el cual la autoridad real y los súbditos del rey de los distintos reinos de la monarquía hispánica establecieron un pacto político común de lealtad y obediencia a un soberano no presente en sus tierras, lugar que el virrey como "viva imagen del rey” procuró ocupar con la clara intención de conservar el orden político y de autoridad de ese espacio de la monarquía. ${ }^{1}$

Bajo ese argumento podemos observar que la proclamación y celebración real que la ciudad de México hizo en honor de Luis I como "rey y señor de las Españas” en 1724, a través de sus distintas corporaciones y figuras de autoridad política, constituye un episodio particular de estudio para este trabajo en el que se podrán analizar los distintos mecanismos de formación política entre los actores sociales involucrados. Aspecto al que se debe sumar el que este hecho histórico sea prácticamente desconocido en la histo-

1 Cañeque, “El poder transfigurado. El virrey como la 'viva imagen del rey' en la Nueva España”, pp. 301-303. 
riografía novohispana. Posiblemente, el carácter efímero del reinado del joven monarca de apenas 17 años ha sido motivo para que los historiadores se interesen poco en las fiestas y exequias que se organizaron en las distintas ciudades de la monarquía hispánica para honrar su memoria. ${ }^{2}$

No obstante, dentro de la documentación manuscrita e impresa sobre las fiestas renacentistas y barrocas que se organizaron en las Indias para celebrar el ascenso de un nuevo rey, podemos encontrar invaluables testimonios del poder político y económico de distintos gremios e instituciones novohispanas, como aquél que mandó elaborar el gremio de plateros de la ciudad de México para exaltar su participación al celebrar la coronación de Luis Fernando de Borbón como monarca. A partir de este testimonio podremos apreciar la concepción que tuvo la sociedad indiana de la autoridad dentro de un tiempo, un espacio y con la participación de unos actores congregados en torno a una corporación artística.

Este trabajo ha sido estructurado en dos secciones. En la primera se buscará dar un esbozo general del lugar que tenía la Nueva España dentro de la monarquía hispánica, espacio que se configuró desde sus cimientos renacentistas como un mosaico pluricultural regido por una misma religión defendida por un monarca, quien tuvo que construir una serie de relaciones de autoridad con sus súbditos por medio de la figura del virrey o de distintos mecanismos políticos y culturales, como la fiesta pública. En la segunda y última sección se analizarán estos mecanismos de la formación política por medio de un episodio poco conocido dentro de la historia de la lealtad indiana hacia la Corona, que fue el juramento que hizo la ciudad de México a Luis de Borbón, a partir del testimonio que dejó escrito el Arte de platero de México y que resguarda actualmente la Biblioteca Nacional de España. Como complemento a este trabajo se incorporó un breve anexo documental con las descripciones sobre las festividades de la coronación.

\section{LA NUEVA ESPAÑA EN LA MONARQUÍA HISPÁNICA, SIGLOS XVI-XVIII}

De acuerdo con Marcello Carmagnani, la incorporación de los espacios americanos a la esfera monárquica española se realizó mediante el recurso jurídico de la invasión y conquista que, una vez bajo el control español, ya fuese mediante la guerra o por medio de un pacto con los señores naturales,

2 Existen algunos estudios de caso sobre esta proclamación dentro de la historiografía española contemporánea, véanse: García, La proclamación de Luis I en Borja, 47 pp., y Serrano, “La proclamación de Luis I: la nueva ceremonia para un viejo reino”, pp. 371-390. 
fueron sometidos a una serie de mecanismos de articulación para estrechar un sólido vínculo con la corte y los diferentes aparatos de la monarquía. ${ }^{3}$ Estos aparatos de cohesión, de acuerdo con Carmagnani, fueron de corte ideológico (religión), cultural (calidad española o portuguesa), institucional (traslado de las instituciones peninsulares) y social (mediante una estructuración estamental, reafirmado tiempo más adelante por el fenotipo), garantizando así la integración de las sociedades indianas dentro de la gran monarquía católica.

Este proceso formativo y de consolidación del espacio americano incorporado a la monarquía española, por medio de la adecuación y reelaboración, fue el que permitió que se trasladaran las formas económicas, sociales, políticas y culturales de la Península Ibérica hasta el Nuevo Mundo, pero ¿cómo se construyeron las relaciones de poder entre el monarca y sus súbditos americanos?, ¿qué ocurrió con las figuras de autoridad política en el territorio, en particular con la del rey como gobernante?

Partiendo de la tesis de Adeline Rucquoi sobre Imperium y TierraNaturaleza, al unirse mediante un proceso asociativo las coronas de los reinos de Castilla-León y Aragón durante la segunda mitad del siglo XV, la nueva organización política de la Península Ibérica, basada en la tradición jurídico romana del Imperium, permitió que este grupo de reinos pudieran ser gobernados bajo un mismo señor. ${ }^{4}$ La figura de este rey común — que se iniciaría con Carlos de Gante- no tenía la pretensión de uniformar a los diversos reinos que estuviesen bajo su potestad a partir de una misma lengua y leyes, como fue el caso de los reyes franceses que homogeneizaron sus dominios bajo el concepto "patrimonial", sino el de salvaguardar el bien común de los reinos bajo una misma religión —que fue la cristiana- otorgándole fuerza de ley y principios para sostener un imperio en el espacio peninsular ibérico a la usanza romana.

La presencia de Dios como fundamento legal e ideológico para establecer un imperio hispano cristiano, permitió que el rey con poderes imperiales gozase del título de vicario de Dios en la tierra, situación por medio de la cual pudo negociar con la Santa Sede la obtención de distintas concesiones y, más adelante, extender sus dominios hacia otras latitudes como parte de una política confesional. Al ser el rey protector de la religión de sus naturales, la tierra que tenía bajo su administración directa facultó el rey para con-

3 Carmagnani, "La organización de los espacios americanos en la monarquía española (siglos XVI-XVIII)”, p. 331.

4 Véase Rucquoi, “Tierra y gobierno en la Península Ibérica”, pp. 51-62. Proceso asociativo: consistente en la existencia de una unidad de reinos heterogéneos que conservaban sus costumbres, privilegios y nombres propios. 
vertirse en señor natural de ésta por la relación íntima que sostenía con el poder divino, de la que derivaba su responsabilidad de velar por la tierra y los intereses de quienes la habitaban, que eran naturales y no súbditos en primer término.

De esta manera, al estar integrada la monarquía española por un conglomerado de tierras y de habitantes bajo el poder de un mismo soberano, las conquistas de nuevas tierras dentro y fuera de la península fueron percibidas por la sociedad como un don que Dios le otorgó al monarca para que las gobernase bajo su protección, dotándoles de lengua y religión comunes. Estos elementos integradores no atentaban contra el principio de conservación de las diferencias que debía poseer cada reino del mosaico pluricultural de la monarquía. Como resultado de esta construcción político-cultural de gobierno que lograron edificar los reyes españoles, los naturales de sus reinos podían llegar a apoyar u oponerse a la implementación de una serie de políticas reales con la intención de salvaguardar el bienestar de la res publica. Así fue como se construyeron las relaciones entre el rey y los naturales de la tierra que tenía bajo su protección, acuerdo común que desde el siglo XV hasta el XIX se fue reconfigurando de acuerdo con las necesidades de los súbditos americanos y de la propia Corona, y que analizaremos más adelante en el caso de la Nueva España por medio de una expresión en particular.

Durante la época colonial ningún monarca español pisó el suelo americano; esta ausencia no fue del todo importante para la población, pues su soberano estaba presente durante las fiestas civiles por medio de un lienzo pintado, de sus insignias reales o por alguna otra representación que tenía como función hacer gala de su presencia no corpórea. ${ }^{5}$ El éxito y aceptación de este recurso no podría ser explicado sin la fiesta que —en palabras de Nelly Sigaut - fue la fórmula de sociabilidad que conjugó un auténtico aparato de ceremonia de procedencia mixta. Por un lado, se mostraba el poder del rey ante la comunidad y por otro se reproducía simbólica y materialmente hacia la colectividad para reafirmar los fundamentos de su legitimidad. ${ }^{6}$

La clave de este poder del monarca simbólicamente expresado en la fiesta pública estaba claramente en lo que se ve, se muestra y manifiesta

5 Sigaut, "La circulación de imágenes en fiestas y ceremonias y la pintura de Nueva España”, pp. 406-407.

Ibíd., p. 401. Sobre la importancia de las celebraciones reales en los gobiernos americanos y del espacio urbano para su realización, véase: Martínez Hernández, “Cultura festiva y poder en la monarquía hispánica y su mundo: convergencias historiográficas y perspectivas de análisis”, pp. 139-143,147. Otros textos que abordan esta misma temática: Méndez, Fiesta y celebración: discurso y espacio novohispanos. 
hacia el público — de acuerdo con Michel Foucault—, ${ }^{7}$ de ahí que cualquier acto público que expresara felicidad y regocijo, como la canonización de un santo o el nacimiento de un miembro de la familia real, o infortunio y desconsuelo, como la relajación en el fuego de un reo inquisitorial o la muerte del propio rey, eran los medios por los cuales se reactualizaban en el tiempo los efectos del poder. ${ }^{8}$

Dentro de esta fórmula de sociabilidad, es posible encontrar otros sentidos y alcances que podría tener la fiesta pública en el mundo hispánico. Sería un error señalar que este tipo de eventos constituían una mera y simple muestra de "lealtad y obediencia" hacia el soberano ausente expresada en actos simbólicos discursivos; también fueron aprovechados por aquellos vasallos congregados en corporaciones políticas, económicas y religiosas para proyectar o rectificar visualmente su autonomía y poderío dentro del propio orden social y corporativo encabezado por el monarca. ${ }^{9}$ Este acto demuestra que a lo largo de su existencia la sociedad hispánica poseyó un carácter mutable y complejo con múltiples niveles de organización política, así como de estructuras de poder social con sus propias proyecciones que respondían a fines particulares.

Por otra parte, ¿cómo se podría explicar esta lealtad y legitimidad del rey español socialmente hablando desde el otro lado del Atlántico? De acuerdo con Alejandra Osorio, el rey era la cabeza de la comunidad que gobernaba, razón por la que su presencia - física o virtual o simbólica - era imprescindible en los actos públicos y privados. En el caso particular de los virreinatos americanos, en comparación con la Península donde el monarca podía hacerse presente en la celebración de algunos de los reinos castellanos o aragoneses, su presencia se convirtió en un asunto complejo al que pronto se le buscó una solución. ${ }^{10}$ Las ceremonias reales celebradas en las catedrales, los palacios reales y las plazas públicas indianas para honrar el nacimiento, el matrimonio, el juramento o la muerte del monarca ausente tuvo como prin-

7 Foucault, Vigilar y Castigar. Nacimiento de la prisión, pp. 52-62.

8 Cañeque, "El poder transfigurado. El virrey como la 'viva imagen del rey' en la Nueva España”, p. 309.

9 Para entender un poco más de la proyección o rectificación de las corporaciones sociales hispánicas por medio de las ceremonias públicas, las fiestas y procesiones, así como de sus conflictos y actos de violencia para dejar de forma clara su posición dentro de la jerarquía social, se sugieren los siguientes trabajos: Curcio-Nagi, "Giants and Gypsies: Corpus Christi in Colonial Mexico City”, pp. 1-26; Juan Pedro Viqueira Albán, ¿Relajados o reprimidos? Diversiones públicas y vida social en la ciudad de México durante el Siglo de las Luces, pp. 15-32, y Ruíz, Fiestas y procesiones en el mundo colonial novohispano: los conflictos de preminencia y una sátira carnavalesca del siglo ХVIII, $54 \mathrm{pp}$.

10 Osorio, "El rey en Lima, simulacro real y el ejercicio del poder en la Lima del diecisiete", pp. 231-232. 
cipal intención unirlo, mediante "un pacto político reciproco", ${ }^{11}$ con sus súbditos y así afirmar "la verdadera y real unión que los ligaba”.

Junto a este recurso ceremonial debe recordarse el papel político que tenía el virrey como "viva imagen del rey", que, al estar presente en procesiones y ceremonias, debía asumir o encarnar la autoridad regia actuando como si fuera el propio rey en persona por la delegación que el soberano hizo de su poder. ${ }^{12}$ Esta facultad sólo podría ser explicada en el sentido de que "la Monarquía hispánica estaba concebida de tal manera que el poder, en cualquiera de sus manifestaciones, era siempre reflejo de una instancia superior”, ${ }^{13}$ manifestaciones que iban desde la figura política más sencilla, como el cabildo, hasta el virrey y los oidores de la Audiencia. Por esta razón, las distintas figuras de la autoridad político local —entiéndanse éstas como los alcaldes y regidores - fueron los agentes fundamentales que contribuyeron a la construcción del Estado colonial. ${ }^{14}$

Fue a partir de este simulacro de la autoridad real que el poder y la figura del soberano en cualquiera de sus dominios, desde la Nueva España hasta las Filipinas, era tan vivo a pesar de no estar físicamente. Sirva de ejemplo el caso que señaló Alejandra Osorio sobre el virreinato del Perú en el siglo XVII: "El rey tenía un cuerpo original —biológico- que residía en España, pero su simulacro residía en Lima, y cuando éste se desplegaba en rituales públicos elaborados [por medio de una escultura o lienzo] le permitía a sus vasallos distantes pero leales 'verlo, oírlo, y sentirlo' como si él realmente estuviese allí”. ${ }^{15}$

Este pacto político de común acuerdo entre el rey residente en la Península Ibérica y el súbdito novohispano (por referir el caso particular de este virreinato americano) no se limitaba a la fastuosidad que este último podía derrochar en monumentos y altares para expresar su fidelidad al monarca, sino que también abarcaba el ámbito de la ciudades y villas — como señala Solange Alberro- - las cuales estaban relacionadas con los procesos históricos que habían dado origen a la formación de los reinos que representaban. ${ }^{16}$ Reinos que sin perjuicios, antigüedad e importancia política estaban estre-

11 Ídem.

12 Véase Rivero Rodríguez, La edad de oro de los virreyes. El virreinato en la Monarquía Hispánica durante los siglos XVI у ХVII, pp. 97-112, 175-181, Cardim y Lluis Palos, El mundo de los virreyes en las monarquías de España y Portugal.

13 Cañeque, “El poder transfigurado. El virrey como la ‘viva imagen del rey’ en la Nueva España”, p. 311.

14 Ibíd., p. 303.

15 Osorio, "El rey en Lima, simulacro real y el ejercicio del poder en la Lima del diecisiete", p. 234; Bravo, "La fiesta pública: su tiempo y espacio”, pp. 454-458.

16 Alberro, "Reyes y monarquía en las fiestas virreinales de la Nueva España y del Perú”, pp. 288-289. 
chamente relacionados por un lazo de súbditos o "vasallaje” que los hacían parte del mosaico pluricultural que fue la monarquía planetaria de los Austrias y los Borbones.

En el siguiente apartado se analizarán los elementos que garantizaron la presencia del rey en sus dominios americanos por medio de la lealtad expresada de sus súbditos congregados en corporaciones y ciudades, en el que la fiesta pública ocupó un lugar importante dentro del desarrollo de expresiones del poder real y corporativo. Este análisis se hará por medio del caso histórico de la jura que la ciudad de México hizo a Luis I de España y que veremos a través del testimonio que dejó uno de los más importantes y poderosos gremios de artesanos de la ciudad. A partir del caso del arte de plateros se cuestionará la particularidad de la tesis de Alejandra Osorio, la cual sostiene que desde el primer rey borbón dejó de ser exhibido el retrato del soberano en las plazas mayores - por lo menos en el caso de Lima, que es el que ella estudió-, y que, para la proclamación de Carlos III la “cara y cuerpo” del rey desaparecieron completamente. ${ }^{17}$

\section{LAJURA DE LA CIUDAD DE MÉXICO A LUIS FERNANDO I COMO REY DE LAS ESPAÑAS}

Desde la segunda mitad del siglo XVI hasta el cenit del siglo XVII, la ciudad de México se fue consolidando como la urbe más importante del Nuevo Mundo por su forma y contenido. Sobre la forma, la organización política, económica y social de la ciudad se configuró a partir de la traza que los españoles fijaron en los primeros años de su establecimiento en el territorio, lugar donde se establecieron las principales corporaciones religiosas — representada por la catedral, las iglesias y los conventos-, políticas —el palacio virreinal y las instituciones civiles - y económicas — tales como el Consulado de Comerciantes de México y los mercados públicos. En lo que respecta a contenido, éstas determinaron sus espacios simbólicos de poder dentro del nuevo mapa geopolítico de la cuenca del Valle de México, en particular a los alrededores de la plaza de armas que actualmente se llama “Zócalo”. Posiblemente el rasgo más singular dentro de este proceso fue el de su población, la cual empezó a desbordar los límites geométricos de la ciudad española y a establecer fuera de la traza un desarrollo urbano desordenado.

17 Osorio, "El rey en Lima, simulacro real y el ejercicio del poder en la Lima del diecisiete", p. 257. 
Unos cuantos años antes de la llegada del primer rey borbón al trono español, la ciudad de México en 1697 — de acuerdo con las observaciones de un viajero napolitano - se encontraba determinada por el carácter natural de su entorno. Las montañas que encierran la cuenca del valle de México, eran el punto de nacimiento de muchos ríos que desembocaban en las tres principales lagunas del territorio: Ecatepec, Chalco y Texcoco. De esta manera, la ciudad lacustre, a pesar del inminente riesgo que podía representar su carácter acuífero en ciertas estaciones, poseía una forma cuadrada que parecía un hermoso tablero "por sus calles rectas, anchas y bien adoquinadas, orientadas hacia los cuatro vientos cardinales". ${ }^{18}$ Tenía cuatro calzadas que comunicaban a la ciudad-islote con la tierra firme: La Piedad, San Antonio, Guadalupe, San Cosme y Chapultepec.

Sobre el interior de la urbe, el viajero refiere que sus edificios y ornamentos eran tan buenos que competían en firmeza con los mejores de Italia. Había 22 conventos de monjas y 29 de frailes de diversas órdenes religiosas, ${ }^{19}$ parroquias, algunos hospitales atendidos por las diferentes órdenes hospitalarias, edificios del gobierno civil, y las residencias de distintos españoles y criollos que iban desde la más modesta casa hasta el más rico y adornado palacio. En el centro de este tablero se encontraba la plaza de armas, sede de los tres principales poderes del virreinato de la Nueva España: el político, representado por el palacio real y sus espacios interiores; el religioso, donde la inacabada catedral, sede de la iglesia metropolitana, era la construcción que dominaba el escenario por su magnificencia; y el económico, caracterizado por el mercado de El Parián, donde la mayor parte de los miembros del Consulado de Comerciantes de México controlaban la distribución y venta de mercancías de la ciudad. Ésta era la ciudad de México, lugar donde vivían cerca de cien mil personas, en su mayoría negros y castas, y que hacia 1724 presentaba pocas modificaciones en su composición.

Fue en esta dinámica ciudad americana donde el gremio de plateros, bajo la protección del beato Felipe de Jesús, edificó su poder económico y cultural. Desde la segunda mitad del siglo XVI, los plateros se constituyeron en una de las corporaciones que adquirieron mayor prestigio y poder en la ciudad de México, muestra de esto se encuentra en su participación durante las festividades de San Hipólito Mártir, patrono de la ciudad, y en la procesión del día de Corpus Christi. ${ }^{20}$ En términos corporativos y sociales, los plateros se caracterizaron por poseer una definida y clara organización laboral y jurídica, representada en sus ordenanzas interiores que regulaban los meca-

19

20 Sanz, Una hermandad gremial. San Eloy de los plateros, 1341-1914, p. 83 
nismos de ingreso y capacitación de aprendices, ensayadores y oficiales; ${ }^{21}$ de una estrecha relación profesional con distintas instituciones del gobierno virreinal como la Real Casa de Moneda; y, desde luego, por la producción de notables y bellas piezas de orfebrería producidas por varios de sus miembros.

En el ámbito religioso, los plateros se encomendaron y fundaron una cofradía en honor a San Eloy, rasgo en común que compartieron con las otras hermandades gremiales de este oficio en el mundo hispánico. ${ }^{22}$ Poco tiempo después el gremio incorporó a sus devociones a la Inmaculada Concepción, culto en el que sus miembros tuvieron una importante participación en los festejos del 8 de diciembre de 1618 por medio de la manufactura de una imagen de plata de la Inmaculada, así como de la fabricación de un arco en la calle de San Francisco a la altura de la manzana donde se encontraban sus locales. ${ }^{23}$

Debido a la importancia política y económica que alcanzó el gremio de plateros dentro de la sociedad virreinal por el manejo de los metales preciosos, poco tiempo faltó para que estuviera involucrada en una serie de conflictos con la autoridad real debido a que ésta buscó establecer una serie de medidas de control al interior de la corporación. ${ }^{24}$ A pesar de estos problemas, los plateros se constituyeron en una de las corporaciones de mayor influencia social y en una de las más ricas hasta bien entrado el siglo XVIII. ${ }^{25}$

El 14 de enero de 1724, en el Palacio Real de La Granja de San Ildefonso, el rey Felipe V escribió una carta a su primogénito Luis, el príncipe de Asturias, en la que declaró su deseo de abdicar la corona de la monarquía hispánica a favor de él sin referir el motivo particular de su decisión. ${ }^{26}$ Luis, de apenas 16 años y casado con Luisa Isabel de Orleans desde 1722, dos años menor que él, subió al trono unos cuantos días después bajo el título de Luis I, rey de las Españas. ${ }^{27}$ Se desconoce con precisión cuándo llegó la noticia a la Nueva España, en particular a la ciudad corte de México. Tomando en consideración que el sistema de flotas de Indias zarpaba cada año

21 Gutiérrez, “Los gremios y academias en la producción del arte colonial”, p. 27.

22 Sanz, Una hermandad gremial. San Eloy de los plateros, 1341-1914, p. 81.

23 Amerlinck, "Los plateros en la vida social novohispana”, pp. 405-406. Mayores datos sobre la influencia social y económica que tuvo este gremio en los siglos XVI y XVII pueden encontrarse en este trabajo.

24 Véase Ruíz Medrano, El gremio de plateros en Nueva España, 52 pp.

25 Véase Anderson, Art of the silversmith in Mexico, pp. 65-71.

26 Valladares de Sotomayor, Semanario erudito, que comprende varias obras inéditas, criticas, morales, instructivas, políticas, histórica, satíricas, y jocosas, de nuestros mejores autores antiguos, y modernos, pp. 271-277.

27 Larios Martín, Dinastías reales de España. Geografía política y eclesiástica, p. 33. 
de Cádiz entre los meses de abril y mayo, la noticia debió llegar en la primera quincena de julio.

Notificado el virrey Juan de Acuña, marqués de Casa Fuerte, y el resto de las autoridades y tribunales civiles y eclesiásticos del virreinato de tan prodigioso acontecimiento sucedido a principios de ese año, decidieron organizar la celebración pública que exaltaría la preeminencia política y económica de la ciudad de México sobre las ciudades menores del reino. Y así sucedió. La fiesta que fue un tiempo excepcional de celebración dentro de la monotonía de la vida diaria de la sociedad novohispana, cuyo sello fue el valor ritual y colectivo que la caracterizaba, ${ }^{28}$ se hizo presente en el calendario civil y religioso — caracterizado por la periodicidad del festejoreafirmando el pacto político de común acuerdo existente entre el rey ausente y el leal súbdito novohispano para preservar el orden establecido.

De acuerdo con María Dolores Bravo, la autoridad real eligió el tiempo, el lugar y los espacios idóneos para que “el pueblo, ávido siempre de celebraciones, viviera con intensidad los ritos que la Iglesia y el Estado novohispanos presentaban para regocijo... de los sentimientos y de la emotividad de los espectadores”. ${ }^{29}$ Se organizarían para esta circunstancia particular - como era costumbre desde la época de los Habsburgo - una serie de procesiones, torneos literarios, mascaradas ${ }^{30}$ y corridas de toros, donde los gremios más importantes de la ciudad participarían en el festejo haciendo gala de su riqueza y poder.

Se desconoce con precisión la fecha en que dieron inicio los festejos; sin embargo, por el testimonio impreso del gremio de los pintores este arte debió ser una de las primeras corporaciones que abrieron la celebración por medio de una pirámide que montaron — ¿en la catedral?_ el 25 de julio para celebrar la jura del nuevo monarca. ${ }^{31}$ Elisa Vargas Lugo señaló que muchas corporaciones solicitaron quedar exentas de asistir a las ceremonias de esta celebración debido a lo complicado que les resultaba económicamente participar por medio de algún monumento, arco u otra expresión artística concebida para la ocasión. Este no fue el caso del gremio de pintores, aunque personas que se disfrazan con máscaras. Latín. Personata pompa. MUÑ. Vid. de S. Carl. lib. 2. cap. 30. Mandó hacer en Roma rogatívas públicas y oraciones, prohibiendo las máscaras y espectáculos”, en Diccionario de Autoridades, 1726-1739.

31 Véase Breve explicación de lo que contiene la pirámide que para celebrar la jura de nuestro católico monarca Luis I, que Dios Guarde, erigieron los profesores del nobilísimo arte de la pintura en la ciudad de México el 25 de julio de 1724. De este manuscrito no se conoce ningún ejemplar. 
—recalca la investigadora — su participación debió de haber sido más bien modesta a pesar de vivir cierta prosperidad a principios del siglo XVIII. ${ }^{32}$

El día principal en que las autoridades, la nobleza y los religiosos participaron en los festejos, a partir de una "estricta jerarquización de estamentos”, fue la misa que se celebró el 26 de julio en la Santa Iglesia Catedral Metropolitana de México, donde el virrey marqués de Casa Fuerte realizó el juramento solemne a Luis Fernando como rey y señor de las Españas con la asistencia de todos los tribunales de la nobilísima ciudad de México. Se conoce ese momento gracias a que se conservó el sermón que predicó el doctor Lucas de Verdiguer, tesorero de la iglesia catedral y, por aquel entonces, el doctor más antiguo de toda la Real y Pontificia Universidad. El hecho de que este personaje haya sido electo para pronunciar el sermón de jura resulta significante. De acuerdo con lo que Verdiguer señala desde la primera página, él predicó 17 años antes el nacimiento de "nuestro príncipe, rey y señor", y, hace tres años, "se le destinó la fortuna de predicar el juramento que la Noble y Leal ciudad hizo a Luis como Príncipe de Asturias”. El clérigo supo aprovechar la fortuna que nuevamente lo gratificaba, ahora predicando la coronación del rey de las Españas, para reafirmar su pacto de lealtad y fidelidad hacia el nuevo soberano.

Con la intención de retomar en este trabajo algunos de los puntos más importantes del sermón de Verdiguer, encontramos que nuestro personaje exaltó y equiparó por igual las figuras de Felipe V y Luis I por medio de dos personajes bíblicos importantes: David y Salomón, respectivamente. Ambos monarcas, representados en estos dos reyes bíblicos, por medio de sus cualidades y acciones dieron vida a aquel designio divino que el padre Verdiguer refiere: "Aquí pide á Dios que transfiera su Justicia en su hijo, para que vivan en paz los pueblos, y con amparo los pobres; porque aquí por total Renuncia de la Corona, instituye Rey a Salomón”. ${ }^{33}$ Designio que hasta en determinados actos "existió" punto de total semejanza de acuerdo con el eclesiástico:

En Salomón fue verbal el orden para que se coronara, y orden que se le dio al Sacerdote Sadoc, y al Propheta Natán; en Fhilipo fue un Real rescrito, una

32 Vargas Lugo, Curiel, Juan Correa. Su vida y su obra. Cuerpo de Documentos, p. 221.

33 Verdiguer Isasi, El segundo sin segundo Salomón, el Sr. Don Luis Fernando rey y señor de las Españas. Sermón que al juramento que solemnemente hizo el Excelentísimo Sr. Dn. Juan de Acuña, marqués de Casa Fuerte, con asistencia de todos los tribunales y de la Nobilisima y Leal Ciudad de México, 2r. La transcripción se realizó siguiendo la puntuación y gramática original de su época. 


\begin{abstract}
Carta escripta en San Ildephonso el día 14 de enero de este presente año de 24. y es á mi ver por conformarse, y confirmar que aquella Sacramentada mesa, es el diseño, el dibujo de la Corona de LUIS, donde un Padre vivo imbia una Carta para constituir Rey á un Hijo; Eso es hazerse el Divino Verbo Hombre, vistiéndose de la naturaleza humana, y poniéndose la gala como una Carta de letras un Dios y Hombre $[. . .]^{34}$
\end{abstract}

Más adelante el padre Verdiguer señaló que la llegada al trono de Luis I, como la del rey Salomón, iba a ser en pacífica posesión y reinado de quietud, en comparación a la de su padre que, como el rey David, estuvo marcada por tanta sangre; ${ }^{35}$ una posible referencia a la participación de Felipe V en la Guerra de Sucesión de principios del siglo XVIII. Verdiguer recomendó en materia religiosa, posiblemente siguiendo los dictados que Felipe $\mathrm{V}$ dio a Luis I en la carta de abdicación al trono, que el nuevo soberano guardara los preceptos y el temor de Dios mediante la defensa de la religión católica en todo el imperio, velando además por las instituciones encargadas de esta tarea, como el Santo Tribunal de la Inquisición. ${ }^{36}$ Por último, el eclesiástico señaló que Luis I tenía una importante labor como "amparo y defensa de los pobres" que, en el caso de las Indias eran los naturales, porque era su deber divino en consideración a que "[...] los Reynos de España son Reynos de Dios [...] Todas las Coronas las reparte Dios; así nos lo enseña el Espíritu Santo". ${ }^{37}$

Retomando el ambiente de la ceremonia de aquel día 26 de junio en la Santa Iglesia Catedral, Verdiguer nos relata que el virrey fue el primero en jurarle lealtad al nuevo monarca español por medio de su corazón y vida para velar así por los fueros y derechos del "Real Patrimonio", y garantizar así la paz en el gobierno de sus dominios, en este caso de la propia Nueva España. ${ }^{38}$ Después del marqués de Casa Fuerte juró lealtad el arzobispo de México, José Pérez de Lanciego Eguiluz y Mirafuentes, seguido de los tribunales de la ciudad de México.

Por otra parte, se tiene conocimiento de que los festejos en la ciudad de México por la proclamación de Luis I como rey se extendieron hasta el martes 1 de agosto, de acuerdo con el testimonio que nos dejó el gremio de plateros de la ciudad. En el caso particular de este manuscrito inédito que lleva por título Celebración que hizo el ilustre arte de plateros a la coronación de

\footnotetext{
Ibíd., 2r-2v.

Ibíd., 4r.

Ibíd., 7r-7v.

Ibíd., 8r.

Ibíd., 9r-9v.
} 
nuestro católico rey de las Españas (que Dios guarde) Don Luis Primero, de autoría anónima y que fue promovido por el virrey Juan Vázquez de Acuña marqués de Casa Fuerte, el marqués de Vistahermosa - ¿en calidad de mecenas? - y el presidente del gremio de plateros, Don Pedro Avilés, se expresa en sus ocho secciones o títulos la lealtad y obediencia que el "arte de plateros" mantendría al nuevo monarca en agradecimiento a tantas mercedes que su antecesor hizo a esta ilustre corporación. ${ }^{39}$

La participación del gremio de plateros dentro de esta celebración real, tuvo como su máxima expresión de riqueza y posicionamiento social la manufactura de dos monumentos en honor al nuevo monarca: un carro triunfal de plata y un monumento erigido afuera de la casa de Don Pedro Avilés. Estas obras exaltaban las cualidades de Luis I como nuevo gobernante por medio de recursos retóricos y simbólicos barrocos, y que además engrandecían la riqueza e importancia política y cultural que la ciudad de México tenía dentro de la monarquía hispánica.

En las primeras cuatro secciones o títulos del manuscrito, su autor - como portavoz del gremio - presenta la obra y exalta, por medio de tres sonetos y unas décimas, las cualidades del retrato que confeccionaron los plateros para honrar la real persona de Luis I durante los festejos organizados en su honor en la capital del virreinato. Desde un principio el autor mantiene y resalta su calidad de leal, "amante", "amoroso" y obediente — ¿ solamente él o el gremio también?_- vasallo hacia el nuevo soberano, exaltando sus cualidades como la pureza (representada en la figura de la turquesa), de justicia (por medio de la figura del León), la fortaleza, el ímpetu y la heroicidad. Esta descripción concluye con la reafirmación de la lealtad que el platero siempre ha tenido hacia su alteza: "Puesto que siempre se ha empleado/ Amante, leal y verdadero/ En las cosas de su Rey/ Prospere su vida el cielo". ${ }^{40}$

Después de tan "conmovedoras palabras" que profirió el autor anónimo en su calidad de voz del gremio, la descripción que se muestra enseguida detalla la celebración que encabezaron los plateros el 1 de agosto, tomada de la "Celebración que previno la Noble junta de la Platería en su Carro Triumphal á la Coronación y Jura del Catholico Rey de las Españas (q Dios guarde) D. Luis Primero", y que refleja la opulencia y riqueza que poseían en términos políticos y económicos:

Se practicó una primera búsqueda documental de la relación que guardó el gremio de plateros con Felipe V durante su primer reinado y no fue posible encontrar cuáles fueron las mercedes por las cuales se agradece en este manuscrito.

40 "Celebración que hizo el ilustre Arte de Platero a la Coronación de Nuestro Catholíco Rey de las Españas (que Dios Guarde) Don Luis Primero”, México, 1724, BNE, Manuscritos: 7r. 
Al día Martes primero de Agosto, saliese un vistoso, y lucido Carro a expensas de todo el Arte, el qual era (como se muestra el dibujo) despues del vistosísimo por ser todo de Plata de pan bruñida, y labores a punta de sinzel, con tal primor, q parecía de Plata maziza a golpe de martillo, llevaba en la cima sobre un morrión la Fama, y en la Vandero la de su ladina y vocinglera vocina, un mote que decía Viva Luis primero Rey, y después a sus plantas varios despojos de Guerra.

El carro que el gremio de plateros mandó elaborar para tan importante ocasión poseía cuatro ángeles, además de los elementos ya señalados; cada uno tenía una letra que eran V.L.F.I (Viva Luis Fernando I) junto a unas dedicatorias escritas por medio de soneto. El carro llevaba otros dos ángeles, dos leones — cada uno asido con un mundo_- una silla (en la que iba sentada una escultura de Luis I), "las reales armas de su magestad”, las columnas “del Invicto Hércules” con el plus ultra, y un “mar con varios peses y una dezima”.

La procesión que organizó este gremio exhibió ante la sociedad novohispana su prestigio y poder económico a través del carro de plata que elaboraron. En esta marcha iba la propia junta de plateros encabezada por su presidente, Don Pedro Antonio de Avilés, quien portaba “un riquísimo vestido bordado de plata, con el mayor primor, que puede el esmero, el collar y toizon, que le guarnecía de rubies, y diamantes, y el santo espíritu de Diamantes, sombrero con plumas, y Joyel de Diamantes”. ${ }^{41}$ Los demás miembros de la junta, de acuerdo con el autor de este escrito, iban ricamente vestidos al igual que su presidente: "los aderesos de sus Caballos, lo bien adornado de sus Lacayos, y su alagueño Semblante, los esplendores del fuego de su lealtad”. ${ }^{42}$ Los pajes que acompañaban el carro con la figura del rey iban vestidos de terciopelo con fondo azul y blanco, brocados carmesí y franjas de oro, sombreros de plumas, guantes y sin espadas. Por su parte la escolta de soldados, que iba por la parte de atrás al “Carro Triumphal”, todos iban vestidos de azul al igual que los pajes. ${ }^{43}$

El ambiente de tan fastuoso festejo encabezado por los plateros generó bullicio, regocijo y el aplauso por parte de los distintos estamentos de la sociedad novohispana presentes al son del repique de las campanadas de la catedral y de los fuegos pirotécnicos que este gremio pagó durante tres días. El festejo no se limitó a esa expresión de poder y lealtad que este arte

41 Ibíd., 12-r.

42 Ibíd., 12-v.

43 Ibíd., 12v-13r. 


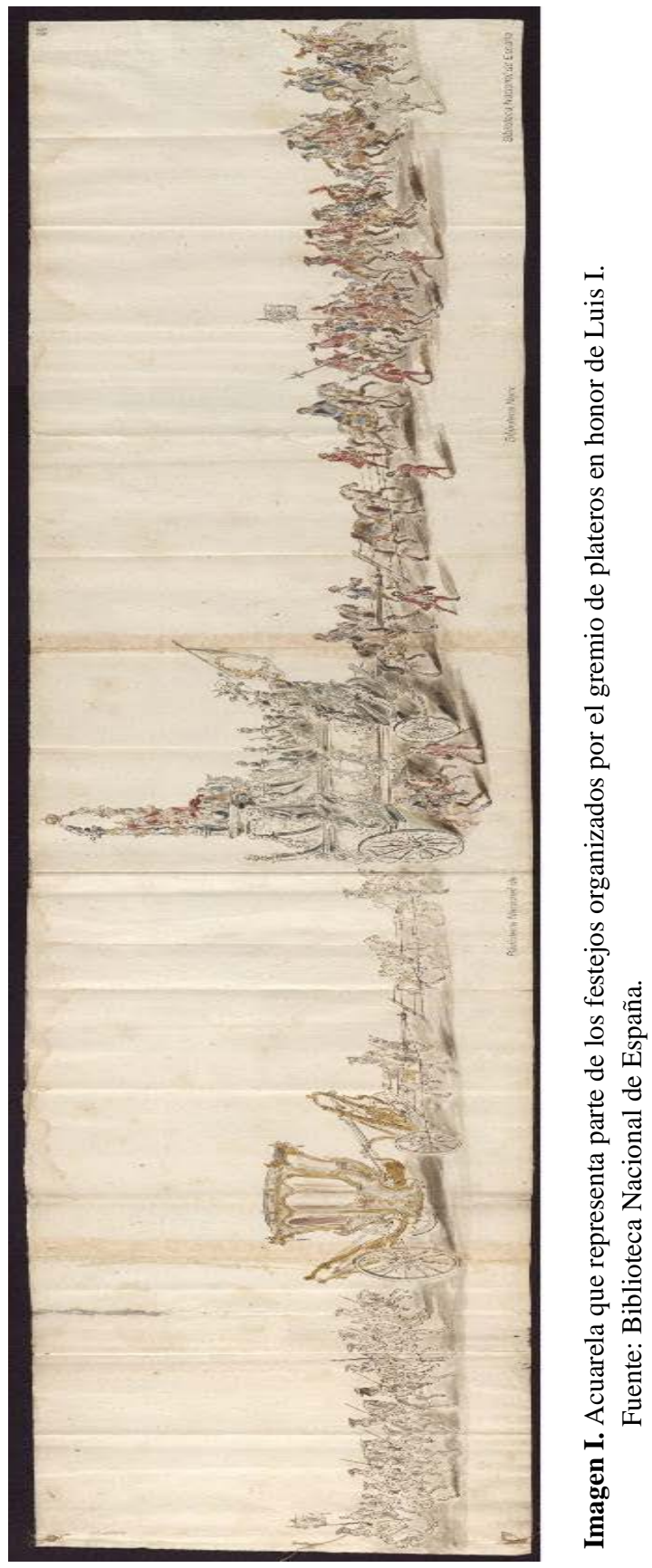


también tuvo lugar un par de cuadras al poniente de la plaza, en la calle de los plateros cerca de la Casa Profesa:

[...] á esto se allegaba el que toda la Calle, que nombran de los Plateros, estaba tan vistosa por las Cortinas, Gallardetes, Vanderas y adorno de Valcones, tan ricamente guarnecidos de palanganas, azafates y fuentes de plata [...] varias puertas y Ventanas se vieron orladas con Oro, Diamantes y Perlas. En los bajos de la Casa de Don Alonso de Avilés, Maestro de Platero, Caveza de este ilustre arte q están en el frente de la Casa Profesa de la Sagrada Compañía de IESUS. Padre del que representó la Magestad Catholica de D. Luis I dejando aparte lo opulento y bien adornado de su Casa; se hallaba un Aparador de diez baras de alto, y ciete de ancho todo de plata con las cosas mas cuzias y exquisitas que es ponderable el medio de piesas doradas, y los lados de plata blanca, quatro Angeles superirmente Vestidos de riquísimas Joyas, uno ofreciendo la Corona, Otro el Ceptro, y los otros dos unos Laureles, hasia enlabor al medio de dho aparador una tarja de dos baras de diámetro y de alto bara y quarta, con dos Angeles abrazándola de bara [...] en el medio de dicha Tarja estaba puesto de perlas gruesas, netas muy legible Luis Fernando; y los huecos, de Diamantes, Esmeraldas, Jazintos, Topacios y varias piedras preciosas, en el remate piramidal un trono dorado y Terciopelo Carmesi con fluecos de oro, y al medio la Augusta Ymagen de Nuestro amantissimo Rey (que Dios guarde) D. Luis I. ${ }^{44}$

El monumento que se levantó afuera de la casa de Don Pedro Alonso de Avilés — por su riqueza y fastuosidad material — fue parada obligada de curiosos y fervorosos súbditos del rey español. Incluso, cuando el virrey marqués de Casa Fuerte quiso apreciar tan majestuosa y solemne obra de arte fue necesario - de acuerdo con el testimonio- que los albarderos le hicieran lugar. El autor de este escrito, además de la exaltación que hizo del gremio de plateros por la magnificencia de la procesión organizada y de haber levantado un monumento honrando la grandeza de Luis I, engrandeció el lugar que tenía la “Noble y Muy Leal Ciudad de México” como escenario de estos festejos por medio de su heroicidad, su nobleza y por poseer la "lealtad de tantos sínceros pechos, gravando en ellos la obediencia legal de amantes corazones". ${ }^{45}$

En el "Romance Poco serio a la Celebridad del Día de la Jura y Coronación...”, el autor reconstruyó, por medio de un relato lo más apegado a la reali- 


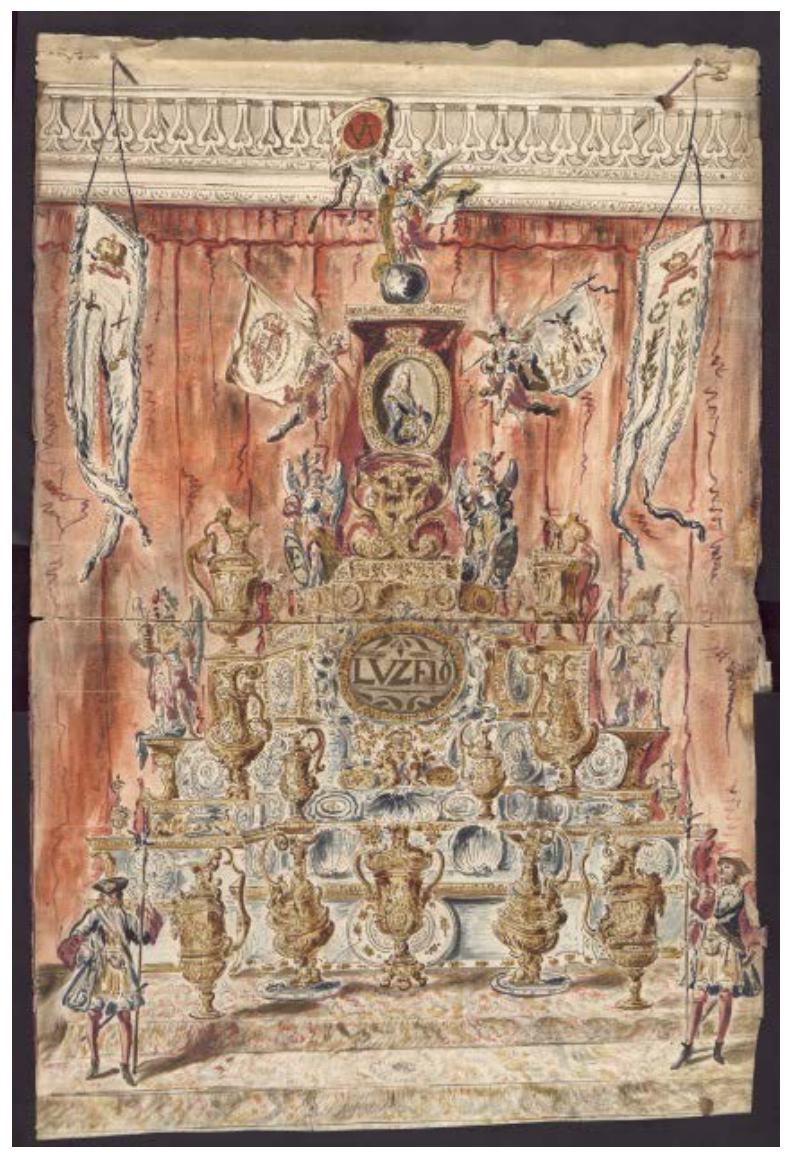

Figura 2. Acuarela a color del Monumento que se levántó en honor a Luis I de España afuera de la casa de D. Pedro Avilés.

Fuente: Biblioteca Nacional de España.

dad, los ánimos de la sociedad novohispana por tan magnánimo festejo desde el 25 de junio hasta el 1 de agosto, y cuyo cierre estuvo a cargo de los plateros. Señala el autor que "Al festín [fueron] las mozas/ Los muchachos, y los viejos/ Por que los niños son niños/ Y como tales traviesos/ De princi- 
pio á fin las Calles Parecian Ormiguero"; ${ }^{46}$ fue tal la concurrencia, que, en su opinión, hasta los médicos renunciaron a los enfermos ${ }^{47}$. A pesar de que ese día las nubes amenazaron por la mañana soltar toda "el Agua/ Sin atención ni respeto", el sol se hizo presente enviando grandes destellos sobre la ciudad. Ya cercana la noche se celebraron juegos de cañas y espectáculo de pirotecnia para clausurar la fiesta. ${ }^{48}$

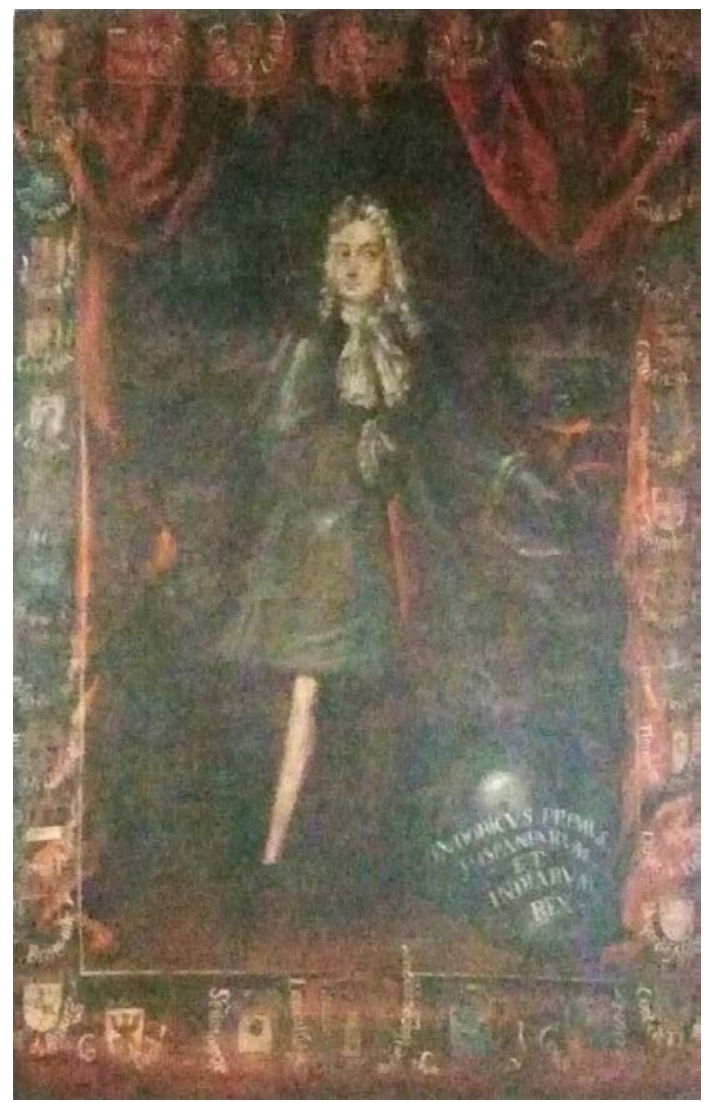

Figura 3. Pintura de Luis Fernando I, ¿siglo XVIII?

46 Ibíd., 17r.

47 Ídem.

48 Ibíd., 20r-20v. 
Fuente: Museo Local de la Evangelización, Ex Convento de San Muguel Huejotzingo.

Así transcurrieron aquellos días en la ciudad de México. Las autoridades civiles y eclesiásticas - en compañía de los tribunales y gremios de la ciudad-celebraron entre la opulencia y el regocijo la coronación de su nuevo César, Luis I, figura del poder real que a los dos meses del festejo y después de tres días de agonía por una viruela benigna entregó su cuerpo a la muerte el 31 de octubre. Parece que esta noticia llegó bastante tarde no sólo a la Nueva España, sino a los rincones más remotos de la monarquía hispánica, como la villa rica del Potosí. En 1725 esta ciudad andina celebró la jura al ya difunto monarca por medio de un desfile encabezado por un carro triunfal en el que se encontraban las figuras de Felipe V, la reina y su hijo Luis. ${ }^{49}$ En el caso de la América Septentrional, de acuerdo con el título de algunos escritos que se publicaron - pero que actualmente se desconoce ejemplar alguno-, en las ciudades de Oaxaca y Durango celebraron en 1725 la jura solemne al segundo rey borbón español. ${ }^{50}$

\section{CONSIDERACIONES FINALES}

La cultura barroca — como refiere Alejandra Osorio - tuvo la ostentación como una de sus principales características, ${ }^{51} \mathrm{y}$ fue este rasgo del que supieron sacar provecho los gremios de mayor prestigio y poder de la ciudad de México, como el de los plateros. La capital del virreinato de la Nueva España se engalanó entre julio y agosto de 1724 con motivo de la coronación de Luis Fernando I como rey de las Españas, hecho sin precedentes que convocó a las distintas instituciones civiles y eclesiásticas, así como a los propios gremios de artesanos, a participar en la jura de la ciudad por medio de procesiones, monumentos y demás expresiones artísticas que hicieran visibles - a través de la ostentación - sus despliegues de riqueza y la exaltación de su lealtad dentro de la fiesta pública. Esta celebración fue considerada en

49 Alberro, "Reyes y monarquía en las fiestas virreinales de la Nueva España y del Perú”, p. 283.

50 Véase Levanto, El sol de oriente y del occidente aplaudidos en la solemne fiesta por la coronación de Don Luis I. Del Valle Guzmán, Relación de las fiestas... con que la... ciudad de Durango... celebró la regia proclamación de... Luis Primero... Sobre las exequias que se celebraron en honor de Luis I desde el mundo indiano, se cuenta con un solo trabajo: Rodríguez Moya, Mínguez Cornelles, “Cultura simbólica y fiestas borbónicas en Nueva Granada. De las exequias de Luis I (1724) a la proclamación de Fernando VII (1808)”, pp. 115143, y Sebastían, “Arte funerario y astrología: La pira de Luis I”, pp. 113-126.

51 Osorio, "El rey en Lima, simulacro real y el ejercicio del poder en la Lima del diecisiete", p. 235. 
su época, de acuerdo con las dinámicas políticas de la monarquía, como un refrendo del pacto político común de lealtad y obediencia entre el soberano y sus súbditos, cuya finalidad fue preservar el orden y la figura de la autoridad real en los dominios de ultra mar.

En la Nueva España las expresiones de riqueza fueron distintas. Iban desde las ceremonias litúrgicas hasta la construcción de elaborados carros alegóricos y monumentos que sirvieron para reafirmar el lazo de "vasallaje" hacia la Corona, las cuales quedaron plasmadas en escritos que estas corporaciones sociales mandaron elaborar para que la figura de autoridad y la sociedad tuvieran conocimiento de este testimonio de lealtad. Respecto de la jura que hizo la ciudad de México a Luis I, de acuerdo con Francisco de Solano, se produjeron - al parecer- ocho escritos, ${ }^{52}$ de los cuales sólo se han conservado tres hasta nuestros días: la Celebración que hizo el ilustre Arte de Platero a la Coronación de Nuestro Catholíco Rey de las Españas (que Dios Guarde) Don Luis Primero (1724), de autor anónimo y que se conserva manuscrito en la Biblioteca Nacional de España; las Letras felizmente laureadas y laurel festivo de letras que con ocasión de la jura de nuestro amado rey y señor Don Luis Fernando I... (1724), de Cristóbal Ruíz Guerra, que fue impreso por José Bernardo de Hogal y que se conserva en la Biblioteca Nacional de España; y El segundo sin segundo Salomón, el Sr. Don Luis Fernando rey y señor de las Españas... (1724) de Lucas de Verdiguer, que fue impreso por los Herederos y la Viuda de Miguel de Ribera y que se conserva en la Frank Melville Jr. Memorial Library de la State University of New York at Stony Brook.

Se desconoce la existencia de algún ejemplar de los otros cinco testimonios escritos del pacto político de lealtad entre la sociedad indiana y la Corona española, que están consignados en la bibliografía. En lo que refiere a la producción pictórica conservada en México, y que posiblemente fue realizada para celebrar la llegada de Luis de Borbón al trono, existe una pintura del joven monarca en el Museo Local de la Evangelización del ex convento de San Miguel Huejotzingo, de autoría anónima, y que se presume fue realizada en el siglo XVIII, de acuerdo con las autoridades de aquel recinto.

La figura o el retrato del rey siguió teniendo un papel preponderante dentro de los actos públicos en la Nueva España durante el siglo XVIII. Ejemplo de ello son las dos acuarelas que el gremio de plateros mandó realizar para evidenciar, por medio de un escrito, su participación en los festejos. Otra muestra es la escultura ecuestre de Carlos IV, elaborada por Manuel

52 Véase Solano, Ciudades hispanoamericanas y pueblos de Indios, pp. 264-265. 
Tolsá, testimonio de gran valor por medio del cual la ciudad de México se posicionó simbólicamente sobre el resto de las ciudades y villas del virreinato con la intención de agradecer los beneficios materiales y privilegios recibidos de la Corona, y, no menos importante, reafirmar su pacto político de lealtad.

Todavía quedan puntos por atender dentro de este estudio sobre la lealtad y las expresiones de poder en la sociedad corporativa novohispana del siglo XVIII, tales como un análisis más ponderado sobre las ideas, valores y creencias que se manifestaron en las ceremonias oficiales en tiempos de los Borbones, así como la intención por parte de las élites novohispanas de recalcar la jerarquización estamental al grado de dotar de un gran valor simbólico y político el ascenso de Luis I al trono español.

\section{APÉNDICE DOCUMENTAL}

CELEBRIDAD QUE PREVINO LA NOBLE JUNTA DE LA PLATERÍA EN SU CARRO TRIUNFAL A LA CORONACIÓN Y JURA DEL CATÓLICO REY DE LAS ESPAÑAS (Q DiOS GUARDE) D. LUIS PRIMERO ${ }^{53}$

Para tan festiva celebridad los encendidos corazones a las llamas, que exhala el amoroso afecto de la lealtad, dispuso el noble congreso del Arte el día martes primero de agosto [de 1724], saliese un vistoso, y lucido carro a expensas de todo el Arte, el cual era (como demuestra el dibujo) después de lo vistosísimo por ser todo de plata de pan bruñida, y labores a punta de cincel con tal primor, que parecía de plata maciza a golpe de martillo, llevaba en la cima sobre un morrión la Fama, y en la vandero la de su ladina y vocinglera vocina, un mote que decía "viva Luis primero", y después a su plantas varios despojos de guerra. Y con cuatro ángeles, cada uno con una letra las cuales eran V.L.F.I que decían "Viva Luis Fernando Primero", y una dedicatoria la cual pondré a la letra en un soneto. Seguianse otros dos ángeles y detrás de ellos dos leones cada uno asido de un mundo entre estos dichos la silla, o solio, y a su vuelta las reales armas, de su majestad (que Dios Guarde) con las columnas del invicto Hércules, con el Plus Ultra, dos vichas que mantenían una corona imperial, y a la espalda de dichas columnas un mar con varios peces y una décima. 
Al solio iba sentado representando la siempre augusta majestad de nuestro animoso rey D. Luis Primero, Don Pedro Antonio de Avilés, este iba con un riquísimo vestido bordado de plata, con el mayor primor, que puede el esmero, el collar y toisón, que le guarnecía de rubíes y diamantes, y el santo espíritu de diamantes, sombrero con plumas, y joyel de diamantes, con dos y varios ornatos de dichos diamantes riquísimos, acompañabanle por delante los artífices de la ilustre junta, tan ricamente vestidos, y adornados de joyas, apostando su ardoroso afecto a la explicación del una amoroso de leal pecho, de estos era crecidísimo el número que después de su bizarro adorno nunca ponderable promulgaba su mucho desuelo, los aderezos de sus caballos lo bien adornado de sus lacayos, y su halagüeño semblante los esplendores del fuego de su lealtad. Los pajes del que representaba a su majestad, iban vestidos de terciopelo fondo azul, y blanco, con chupas de brocado carmesí con franjas de oro, con sombreros de pluma y guantes, y aunque españoles sin espadas, libreas ricas a sus lacayos forlones costosos. Seguía tras el carro triunfal una escolta de soldados todos vestidos de azul al propósito. Más aumentaba a placer el que en la metropolitana iglesia soltaron al repique solemne que solamente se acostumbra privilegiar cuando tiene el reino las celebres noticias de sus majestades. Ponderar la algazara, bullicio, regocijo, y aplauso de nobles, y plebeyos, no es posible, que era tanto cuando pública lo poblado de este reino, y la inquietud de tan festivo aplauso, a esto se allegaba el que toda la calle, que nombran de los plateros, estaba tan vistosa por las cortinas, gallardetes, banderas y adorno de balcones, tan ricamente guarnecidos de palanganas, azafates, y fuentes de plata, que puedo sin ponderación, con verdad decir, que varias puertas y ventanas se vieron orladas con oro, diamantes y perlas.

En los bajos de la casa de Don Alonso de Avilés, maestro de platero, cabeza de este ilustre arte que están en el frente de la Casa Profesa de la Sagrada Compañía de IESUS. Padre del que representó la Majestad Católica de D. Luis I, dejando aparte lo opulento y bien adornado de su casa; se hallaba un aparador de diez varas de alto, y siete de ancho todo de plata con las cosas más cusías y exquisitas que es ponderable el medio de piezas doradas, y los lados de plata blanca, cuatro ángeles superiormente vestidos de riquísimas joyas, uno ofreciendo la corona, y otro el cetro, y los otros dos unos laureles, hacía en labor al medio de dicho aparador una tarja de dos varas de diámetro y de alto vara y cuarta, con dos ángeles abrazándola de vara, y media de plata, con sus bandas azules, en el medio de dicha tarja estaba puesto de perlas gruesas, y netas muy legible Luis Fernando; y lo huecos de diamantes, esmeraldas, jacintos, topacios y varias piedras preciosas, en el remate piramidal, un trono dorado y terciopelo carmesí con flecos de oro, y al medio de la augusta imagen de nuestro amantísimo rey (que Dios Guarde) D. Luis I. A tan celebre regocijo, fue tanto el concurso que queriendo pasar 
el excelentísimo señor Marqués de Casa Fuerte fue necesario le hiciere lugar los alabarderos, no dio fin lo plausible del día, aún sepultado Apolo en el

gabinete de las ondas, pues la noche habiendo tendido a su estrellado manto convidó a las luces para que sobresaliesen más en el espacio de su denegrido capuz. Entonces las hachas de los balcones, y luminarias de las puertas varios artificios de fuego, cohetes y bombas figuraban una vistosa, y artificial Troya, que respiraba incendios, abrazaba en llamas de fogoso amor. Tres días duraron a expensas de dicho congreso los artificios de fuego, el ruido, a lo asara y contento, los más afectuosos aplaudiendo su nuevo rey tan prósperamente que vieron sus rayos alumbrar el día, sin haber experimentado la opaca sombra de la noche, sino que a vista de su gran padre Felipe posee en el abril de sus años el laurel invicto de las Españas. Triaca contra el veneno infame de la envidia. Oh siempre heroica, noble y muy leal ciudad de México; no sólo noble por las ricas venas de ilustran tus minerales, sino por la acrisolada lealtad de tantos sinceros pechos, gravando en ellos la obediencia legal de amantes corazones.

\section{SONETO ${ }^{54}$}

Roma del nuevo mundo, es siglo de oro;

Venecia en planta, en riqueza Tiro;

Corinto en artificio, Cairo en Giro;

En la ley antigua Esparta, en nueva Toro.

Crotón en temple, Delfos en decoro,

En ser Numancia, en abundancia Epiro,

Hidaspe en piedras, en corriente Ciro,

En Ciencia Atenas, Tebas en Tesoro.

Pero en ti gran ciudad, en lo sucinto

hallo nueva Venecia, Atenas nuevas,

Y en nueva Creta, un nuevo laberinto.

Que Roma, Epiro, Esparta, Tiro, y Tebas,

Delfos, Toro, Crotón, Cairo, y Corinto,

Hidaspe, y Ciro, la ventaja llevas.

54 Ibíd., 15v. La transcripción de este soneto se realizó conservando la puntuación y el orden en que fue escrito, sólo se modernizaron las palabras del español antiguo. 


\section{BIBLIOGRAFÍA}

Biblioteca Nacional de España, Manuscritos, Madrid, España.

Frank Melville Jr. Memorial Library, State University of New York at Stony Brook, Nueva York, Estados Unidos de América.

Museo Local de la Evangelización Ex Convento de San Miguel Huejotzingo, Instituto Nacional de Antropología e Historia, Huejotzingo, Puebla, México.

\section{FUENTES MANUSCRITAS E IMPRESAS ${ }^{55}$}

Breve explicación de lo que contiene la pirámide que para celebrar la jura de nuestro católico monarca Luis I, que Dios Guarde, erigieron los profesores del nobilísimo arte de la pintura en la ciudad de México el 25 de julio de 1724, México, Imprenta de José Bernardo de Hogal, 1724.

*Celebración que hizo el ilustre Arte de Platero a la Coronación de Nuestro Catholíco Rey de las Españas (que Dios Guarde) Don Luis Primero, México, 1724.

Levanto, Dionisio, El sol de oriente y del occidente aplaudidos en la solemne fiesta por la coronación de Don Luis I, Oaxaca, Imprenta Herederos de la Viuda de Francisco Rodríguez Lupercio, 1725.

*Ruíz Guerra y Morales, Cristóbal, Letras felizmente laureadas y laurel festivo de letras que con ocasión de la jura de nuestro amado rey y señor Don Luis Fernando I brotó por el celeste suelo de su Real, Pontificia Academia, Atenas de las Indias Occidentales y ofrece en nombre de esta Ilustre y Muy Leal Universidad Pontificia, México, Imprenta de Bernardo de Hogal, 1724.

Valle y Guzmán, Francisco del, Relación de las fiestas... con que la... ciudad de Durango... celebró la regia proclamación de... Luis Primero..., México, Imprenta de José Bernardo de Hogal, 1725.

*Verdiguer Isasi, Lucas de, El segundo sin segundo Salomón, el Sr. Don Luis Fernando rey y señor de las Españas. Sermón que al juramento que solemnemente hizo el Excelentísimo Sr. Dn. Juan de Acuña, marqués de Casa Fuerte, con

55 Las obras que se consignan con un asterisco son las únicas de las que se conoce algún ejemplar impreso o manuscrito. Sobre el resto de las fuentes manuscritas e impresas que se refieren en este apartado sólo se tiene noticia de su existencia, pero no hay algún ejemplar en las principales bibliotecas de América Latina, Europa y los Estados Unidos. 
asistencia de todos los tribunales y de la Nobilisima y Leal Ciudad de México, México, Imprenta de Herederos Viuda de Miguel de Ribera, 1724.

\section{OBRAS Y REFERENCIAS}

Alberro, Solange, "Reyes y monarquía en las fiestas virreinales de la Nueva España y del Perú”, Óscar Mazín (ed.), Las representaciones del poder en las sociedades hispánicas, México, El Colegio de México, 2012, pp. 275-300.

Amerlinck, María Concepción, “Los plateros en la vida social novohispana”, Jesús Paniagua Pérez y Nuria Salazar Simarro (coords.), La plata en Iberoamérica, siglos XVI al XIX, México, Instituto Nacional de Antropología e Historia, Universidad de León, 2008, pp. 403-419.

Anderson, Art of the silversmith in Mexico, 1519-1936, vol. 1, New York, Oxford University Press, 1941.

Bravo, María Dolores, "La fiesta pública: su tiempo y espacio”, Antonio Rubial García (coord.), Historia de la vida cotidiana. La ciudad barroca, tomo II, México, El Colegio de México, Fondo de Cultura Económica, 2012, pp. 435460.

Cañeque, Alejandro, “El poder transfigurado. El virrey como la 'viva imagen del rey’ en la Nueva España”, Óscar Mazín (ed.), Las representaciones del poder en las sociedades hispánicas, México, El Colegio de México, 2012, pp. 301336.

Cardim, Pedro y Joan Lluis Palos (eds.), El mundo de los virreyes en las monarquías de España y Portugal, Madrid, Iberoamericana, Frankfurt, Vervuet, 2012.

Carmagnani, Marcello, "La organización de los espacios americanos en la monarquía española (siglos XVI-XVIII)”, Óscar Mazín y José Javier Ruíz Ibáñez (eds.), Las Indias Occidentales, procesos de incorporación territorial, México, El Colegio de México, 2012, pp. 331-356.

Curcio-Nagi, "Giants and Gypsies: Corpus Christi in Colonial Mexico City”, William H. Beezley, Cheryl English Martin y William E. French (eds.), Rituals of rule, rituals of resistance: Public celebrations and popular culture in Mexico, Willmington, Delaware, A Scholarly Resources Inc, 1994, pp. $1-26$.

Foucault, Michel, Vigilar y Castigar. Nacimiento de la prisión, Buenos Aires, Siglo XXI, 2002.

García Rivas, Manuel, La proclamación de Luis I en Borja (reproducción facsimilar de la obra editada en aquella ocasión), Borja, Centro de Estudios Borjanos, Institución “Fernando el Católico”, 2011. 
Gemelli Careri, Giovanni Francesco, Viaje a la Nueva España, estudio preliminar, traducción y notas de Francisca Perujo, 2a. ed., México, Universidad Nacional Autónoma de México, Coordinación de Humanidades, 2002.

Gutiérrez, Ramón, “Los gremios y academias en la producción del arte colonial”, Ramón Gutiérrez (coord.), Pintura, escultura y artes útiles en Iberoamérica, 1500-1825, Madrid, Ediciones Cátedra, 1995, pp. 25-50.

Larios Martín, Jesús, Dinastías reales de España. Geografía política y eclesiástica, Madrid, Instituto Luis de Salazar y Castro, Hidalguía, 1986.

Martínez Hernández, Santiago, “Cultura festiva y poder en la monarquía hispánica y su mundo: convergencias historiográficas y perspectivas de análisis”, Studia Histórica: Historia Moderna, vol. 31, Salamanca, marzo, 2011, pp. 127-152.

Méndez, María Águeda (ed.), Fiesta y celebración: discurso y espacio novohispanos, México, El Colegio de México, 2004.

Osorio, Alejandra, "El rey en Lima, simulacro real y el ejercicio del poder en la Lima del diecisiete”, Óscar Mazín (ed.), Las representaciones del poder en las sociedades hispánicas, México, El Colegio de México, 2012, pp. 229-273.

Rivero Rodríguez, Manuel, La edad de oro de los virreyes. El virreinato en la Monarquía Hispánica durante los siglos XVI y XVII, Madrid, Akal, 2011.

Rodríguez Moya, Inmaculada y Víctor Mínguez Cornelles, “Cultura simbólica y fiestas borbónicas en Nueva Granada. De las exequias de Luis I (1724) a la proclamación de Fernando VII (1808)”, Revista CS. Estudios sobre historia y cultura, Universidad Icesi, núm. 9, enero-junio, Cali, Colombia, 2012, pp. 115-143. DOI: https://doi.org/10.18046/recs.i9.1204.

Rucquoi, Adeline, “Tierra y gobierno en la Península Ibérica”, Óscar Mazín y José Javier Ruíz Ibáñez (eds.), Las Indias Occidentales: procesos de incorporación territorial a las Monarquías Ibéricas (siglos XVI a XVIII), México, El Colegio de México, Red Columnaria, 2012: 43-68.

Ruíz Medrano, Carlos Rubén, El gremio de plateros en Nueva España, San Luis Potosí, El Colegio de San Luis, 2001.

- Fiestas y procesiones en el mundo colonial novohispano: los conflictos de preminencia y una sátira carnavalesca del siglo XVIII, San Luis Potosí, El Colegio de San Luis, 2001.

Sanz, María Jesús, Una hermandad gremial. San Eloy de los plateros, 1341-1914, Sevilla, Universidad de Sevilla, 1996.

Sebastían, “Arte funerario y astrología: La pira de Luis I”, Ars Longa, Universitat de Valencia, núm. 2, Valencia, España, 1991, pp. 113-126.

Signaut, Nelly, "La circulación de imágenes en fiestas y ceremonias y la pintura de Nueva España”, Óscar Mazín y José Javier Ruíz Ibáñez (eds.), Las Indias Occidentales: procesos de incorporación territorial a las Monarquías Ibéri- 
cas (siglos XVI a XVIII), México, El Colegio de México, Red Columnaria, 2012, pp. 437-458.

Solano, Francisco de, Ciudades hispanoamericanas y pueblos de Indios, Madrid, Consejo Superior de Investigaciones Científicas, 1990.

Valladares de Sotomayor, Antonio, Semanario erudito, que comprende varias obras inéditas, criticas, morales, instructivas, políticas, histórica, satíricas, y jocosas, de nuestros mejores autores antiguos, y modernos, tomo XI, Madrid, Imprenta de Blas Román, 1788.

Vargas Lugo, Elisa y Gustavo Curiel (eds.), Juan Correa. Su vida y su obra. Cuerpo de Documentos, México, Universidad Nacional Autónoma de México, Instituto de Investigaciones Estéticas, 1991.

Viqueira Albán, Juan Pedro, ¿Relajados o reprimidos? Diversiones públicas y vida social en la ciudad de México durante el Siglo de las Luces, México, Fondo de Cultura Económica, 1987. 